\title{
The Effects of Glen Canyon Dam Operations on Early Life Stages of Rainbow Trout in the Colorado River
}

he Lees Ferry reach of the
Colorado River-a 16-mile
segment from Glen Canyon Dam to
the confluence with the Paria River-
supports an important recreational
rainbow trout (Oncorhynchus mykiss)
fishery. In Grand Canyon, nonnative
rainbow trout prey on and compete
for habitat and food with native fish,
such as the endangered humpback
chub (Gila cypha). Experimental flow
fluctuations from the dam during
winter and spring $2003-5$ dewatered
and killed a high proportion of rainbow
trout eggs in gravel spawning bars,
but this mortality had no measurable
effect on the abundance of juvenile
fish. Flow fluctuations during summer
months reduced growth of juvenile
trout relative to steadier flows. A
high-flow experiment in March 2008
increased both trout survival rates for
early life stages and fish abundance.
These findings demonstrate that Glen
Canyon Dam operations directly affect
the trout population in the Lees Ferry
reach and could be used to regulate
nonnative fish abundance to limit
potential negative effects of trout
on native fish in Grand Canyon.

Background

The Lees Ferry reach of the Colorado River, a 16-mile segment from Glen Canyon Dam downstream to the confluence with the Paria River, supports an important recreational rainbow trout (Oncorhynchus mykiss) fishery. Federal and State agencies introduced rainbow trout to the Lees Ferry reach following construction of the dam. There is increasing evidence that some of the trout produced in this reach move downstream through Marble Canyon to the confluence with the Little Colorado River, an area used by the largest population of the native endangered humpback chub (Gila cypha) in the Colorado River Basin (Coggins,
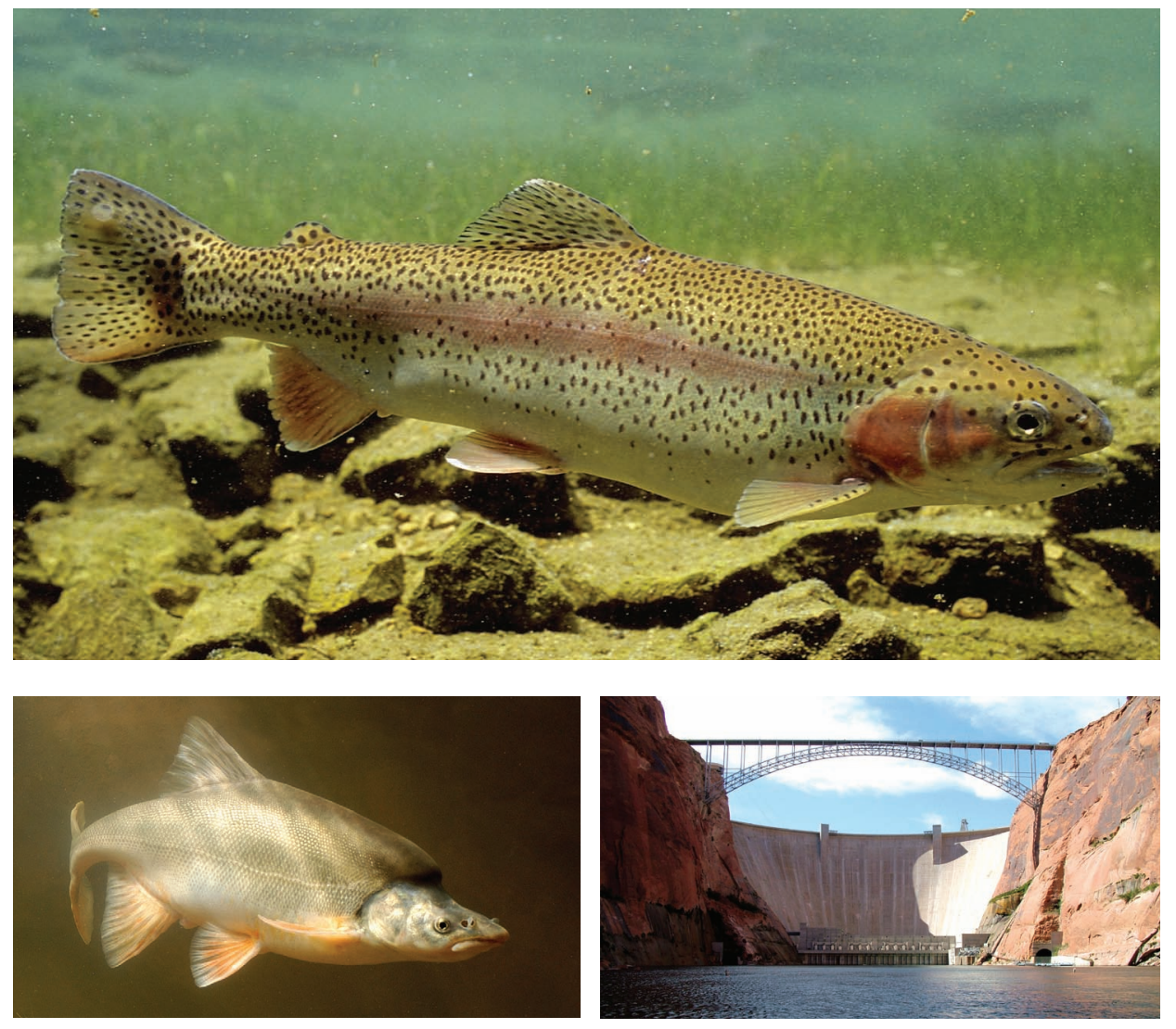

Increased numbers of nonnative rainbow trout (Oncorhynchus mykiss; top) may adversely affect native humback chub (Gila cypha; lower left), an endangered species whose largest population is found in Grand Canyon National Park. Operations of Glen Canyon Dam (lower right) could be used to regulate nonnative fish abundance. (Photos: rainbow trout, (C) Eric Engbretson, used with permission; humpback chub, George Andrejko, Arizona Game and Fish Department; Glen Canyon Dam, (C) Christopher E. Taesali, used with permission.)

2008; Makinster and others, 2010). Adult rainbow trout are known predators of young chub (Yard and others, in press) and also compete with native fish for food and habitat.

In the Colorado River downstream from Glen Canyon Dam, mature rainbow trout spawn during winter through spring. Fertilized eggs are deposited in nests, known as "redds," created by spawning fish in the gravel on the river bottom. Eggs hatch after 1 month, and young trout live as "alevins" in the gravel for another month, nourished by an egg yolk sac that remains attached to their bodies. As the yolk is depleted, the young trout emerge from the gravel as "fry" and begin to feed on drifting aquatic insects. Survival rates for these early life stages can influence the abundance of the adult rainbow trout population. However, reduced abundance at an early life stage can actually lead to increased survival at one or more latter stages because of lower density, which reduces competition for limited food and habitat. Such compensatory survival responses in early life stages are seen in many fish species and may limit the extent to which their abundance changes in response to a decrease in survival at one life stage.

Because of potential negative effects of rainbow trout on humpback chub, fluctuations in flow from Glen Canyon 


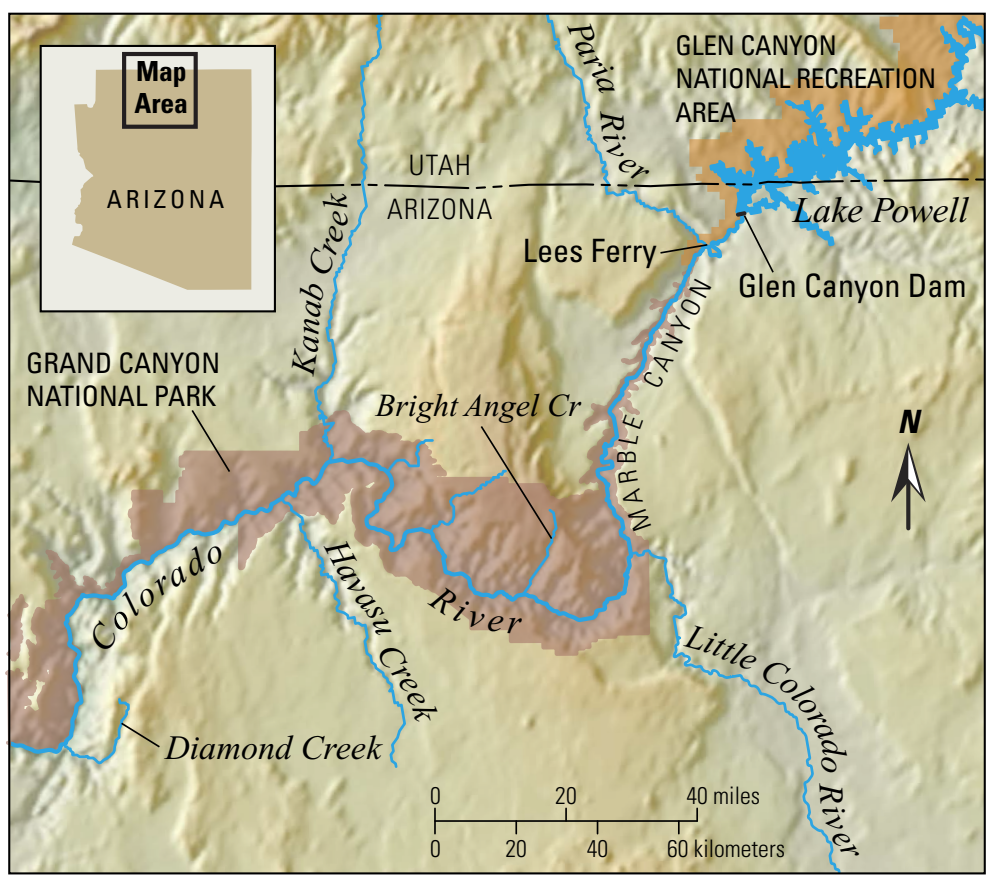

Map of the Colorado River downstream of Glen Canyon Dam showing the study area.

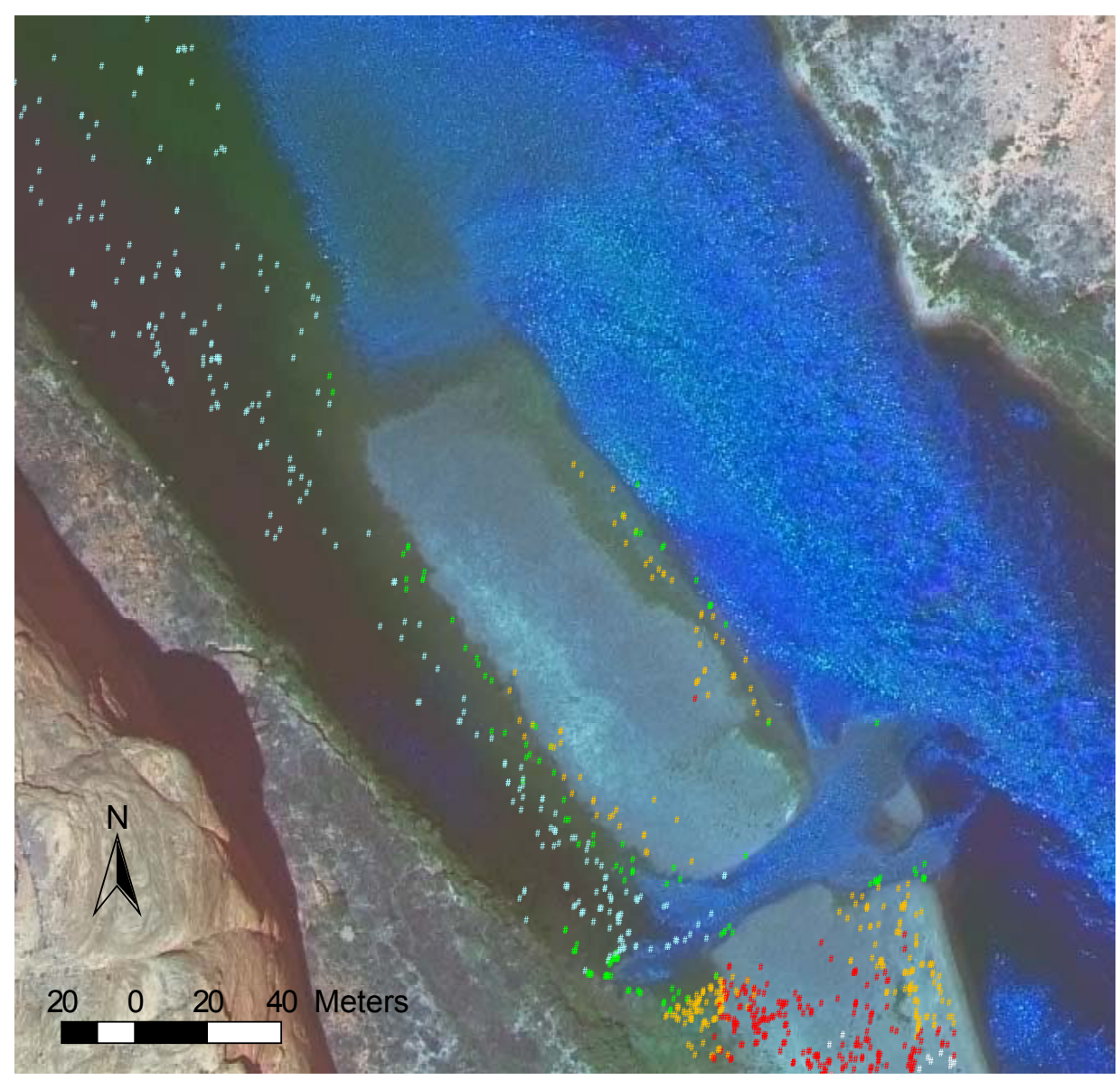

Aerial photograph of a gravel bar in the Lees Ferry reach of the Colorado River, annotated to show by colored dots the locations of rainbow trout redds (nests for spawning) in winter and spring of 2004. The colors indicate the elevation of each redd (light blue are lowest elevations; green, orange, and white are middle elevations; red are highest elevations). Only the light blue redds located at the lowest elevations were permanently submerged during this period. Other redds were dewatered for part of the day because of experimental fluctuating flows, or fish-suppression flows, released from Glen Canyon Dam in January through March of 2003-5. These dewatered redds did not produce viable young because elevated temperatures during the day killed eggs and recently hatched fish.
Dam were increased during January through March of 2003-5 with the intent of reducing the abundance of rainbow trout. In addition, rainbow trout were removed near the Little Colorado River during 2003-6 (Coggins and others, in press). High-flow experiments (HFEs) from Glen Canyon Dam have also been conducted to improve camping beaches and potentially increase the quality of shoreline habitats for native fish in Grand Canyon National Park (Melis and others, 2010). These HFEs also have the potential to affect survival rates for early life stages of rainbow trout, which in turn may affect the abundance of adult trout, the Lees Ferry fishery, and perhaps the survival rates of humpback chub and other native fish. The U.S. Geological Survey (USGS) initiated cooperative research studies in 2003 to evaluate the effects of these experimental dam operations on early life stages of rainbow trout in the Lees Ferry reach. The purpose of this Fact Sheet is to summarize the main findings to date from this research.

\section{Findings}

Increased experimental flow fluctuations during January-March killed 25 and 50 percent of the eggs deposited in the Lees Ferry reach in 2003 and 2004, respectively, because the redds were dewatered and exposed to lethal air temperatures for part of the day (Korman and others, in press). However, the number of fry produced in those years was similar to years under normal operations (2006-7, 2010), because fry from the eggs that were not dewatered had higher survival rates owing to a compensatory survival response.

In contrast, survival rates of early life stages increased more than fourfold following the March 2008 HFE compared to survival rates before the experiment. Fry abundance in 2009 was more than twofold higher than expected, given the estimated number of viable eggs deposited that year, but fry abundance in 2010 was similar to levels between 2003 and 2007. This pattern could indicate that the effect of an HFE on early life stages of trout declines through time, with increased survival rates lasting for as long as 2 years. In 2008, survival rates were much higher for trout hatched about a month after the HFE than for those hatched earlier 
in the year. Fish that hatched a month after the HFE (about mid-April) were not exposed to high flows and emerged into higher quality habitat with greater food availability (Rosi-Marshall and others, 2010). Increased abundance of fry in 2008 eventually led to increased abundance of 1-year-old trout in 2009 in the Lees Ferry reach, and some of these fish likely moved downstream to the area near the confluence with the Little Colorado River (Makinster and others, 2010) used by humpback chub.

Research findings indicate that typical flow fluctuations associated with the modified low fluctuating flow operationsthe operating regime in place since 1996also affect trout in the Lees Ferry reach. Hourly flow fluctuations in summer force rainbow trout fry to stay farther from shore, where it is harder to feed and where water temperatures are cooler, which in turn reduces their growth. Otoliths, minute bony structures found in the inner ear of fish that record patterns of growth, similar to tree rings, were used to evaluate the effects of flow fluctuations on rainbow trout growth. Otoliths examined in 2003 showed a weekly striping pattern, indicating increased trout growth on Sundays, when flows during the day were low and steady compared to other days of the week when flows fluctuated (Korman and Campana, 2009). In 2004, when flows on Sunday were similar to other days of the week, the weekly high-growth striping pattern was not observed.

\section{Management Implications}

These research findings indicate that the operation of Glen Canyon Dam is directly linked to survival rates and production of rainbow trout downstream of the dam, which in turn may affect survival rates of native fish. Reducing rainbow trout abundance by dewatering redds during winter and spring through increased daily flow fluctuations is unlikely to be effective in reducing trout populations because of compensatory survival responses in later life stages. However, increased flow fluctuations during summer may be effective at reducing trout numbers, because these fluctuations negatively affect fry growth and habitat use. Experimental flow fluctuations during summer would likely have to be carried out over successive years to reduce the abundance of the adult trout population. The efficacy of such

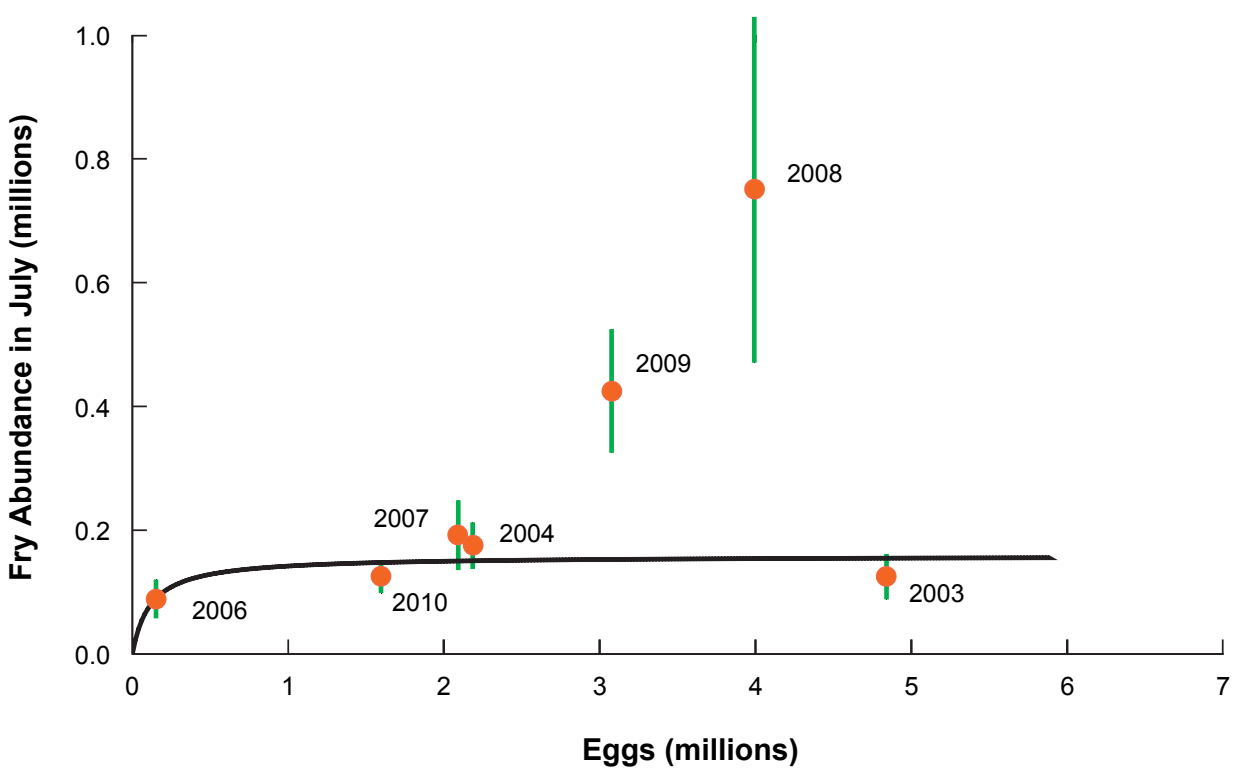

The relation between the number of viable rainbow trout eggs deposited in the Lees Ferry reach and the resulting population size of fry in mid-July for the years 2003-10 (no data for 2005). The thick black curve shows the best-fit relation between viable eggs and fry using data from all years except those affected by the March 2008 high-flow experiment (2008 and 2009), when survival was unusually high. The flat relation indicates that the survival rate from egg to fry stage increases with reduced numbers of eggs, a compensatory effect that minimizes the effect of egg losses on fry abundance. The green vertical lines show the 95-percent confidence limits of fry abundance estimates. (From Korman and others, in press).

\section{Daytime Fluctuating Flows Monday through Saturday}

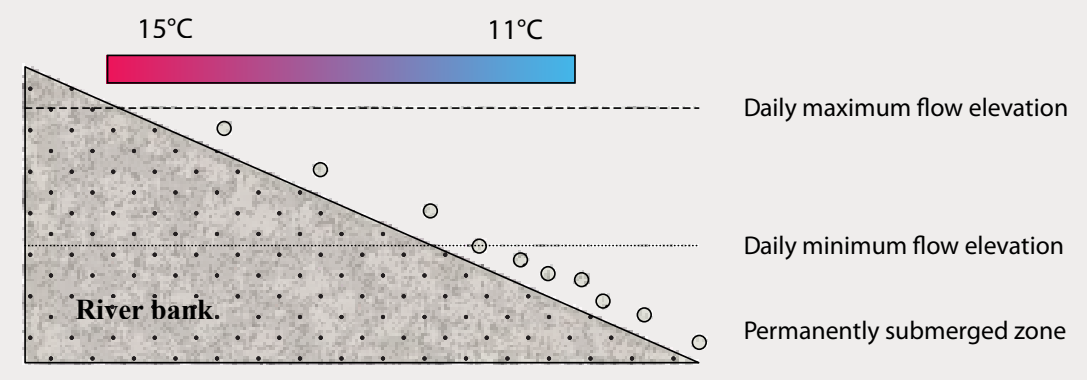

Daytime Low and Steady Flows on Sunday

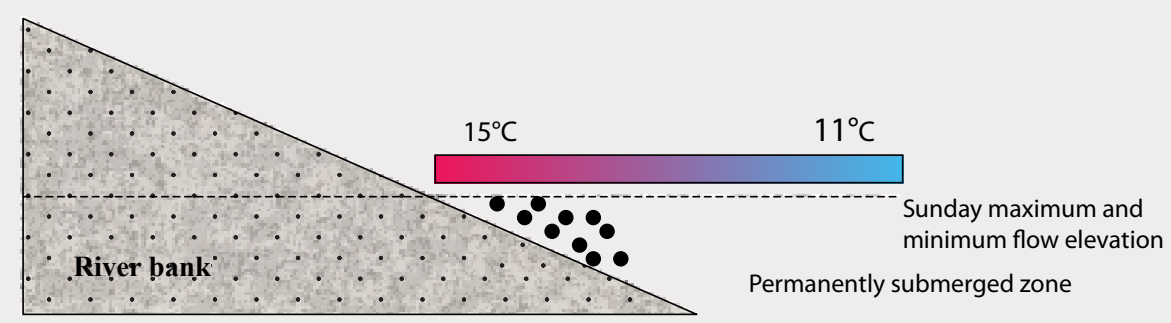

Diagrams showing the effect of fluctuating flows from Glen Canyon Dam on the use of nearshore habitat by rainbow trout fry in the Colorado River (dots denote the locations of individual fish). The shaded area represents the riverbank in cross section. In 2003, when flows fluctuated (high during the day, low at night) from Mondays through Saturdays, most fry remained in the permanently submerged zone and did not migrate up to the immediate nearshore zone during the day. This occurred even though the habitat higher along the riverbank was more suitable for small fish because of warmer water temperatures and lower water velocities and depths. On Sundays, flows were low and steady and most fish were located in the immediate nearshore zone where conditions were better, resulting in improved growth. 


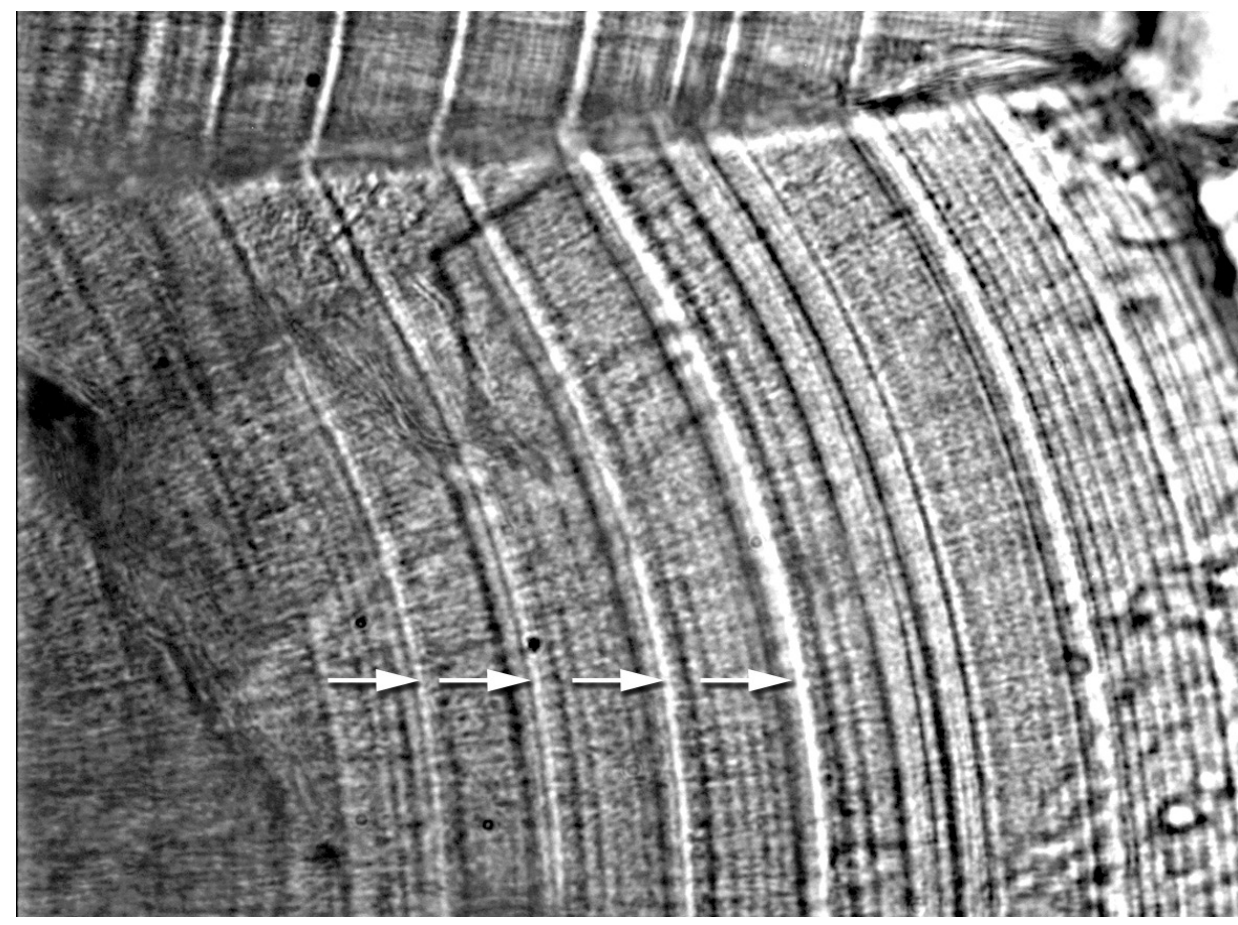

Cross section from an otolith of a $43-\mathrm{mm}$ (1.7 inches) rainbow trout fry that was 81 days old from hatch when sampled on July 30,2003 . Otoliths are minute bony structures found in the inner ear that show daily growth patterns in many fishes. The image (magnified 400 times) shows the weekly striping pattern (identified by white arrows) caused by increased growth during low and steady flows on Sundays. (From Korman and Campana, 2009)

experimental operations would have to be carefully monitored in terms of their effects on trout abundance in both the Lees Ferry reach and downstream in the area of the confluence with the Little Colorado River.

Rainbow trout abundance increased following the March 2008 HFE, in part, because of improvements in habitat and increased food availability for fry. The increase in fry ultimately led to an increase in abundance of older trout in the Lees Ferry reach and likely also downstream in the area of the confluence with the Little Colorado River. If this effect is sustained under repeated HFEs, then expanded control efforts for nonnative fish may be warranted to preserve and restore native fish. On the basis of currently available research, it is uncertain whether future HFEs, with the same or different timing, will produce rainbow trout responses similar to those seen in 2008-9. However, this uncertainty could be resolved if fish responses to future HFEs are closely monitored.

\section{References}

Coggins, L.G., Jr., 2008, Active adaptive management for native fish conservation in the Grand Canyon-implementation and evaluation: Gainesville, University of Florida, Ph.D. dissertation, $173 \mathrm{p}$.

Coggins, L.G., Yard, M.D., and Pine, W.E., in press, Nonnative fish control in the Colorado River in Grand Canyon, Arizona - an effective program or serendipitous timing?: Transactions of the American Fisheries Society.

Korman, J., and Campana, S.E., 2009, Effects of hydropeaking on nearshore habitat use and growth of age- 0 rainbow trout in a large regulated river: Transactions of the American Fisheries Society, v. 138, no. 1, doi: 10.1577/ T08-026.1, p. 76-87, accessed on January 11, 2010, at http:// afsjournals.org/doi/pdf/10.1577/T08026.1.

Korman, J., Kaplinski, M., and Melis, T.S., in press, Effects of fluctuating flows and a controlled flood on incubation success and early survival rates and growth of age- 0 rainbow trout in a large regulated river: Transactions of the American Fisheries Society. Makinster, A.S., Persons, W.R., Avery, L.A., and Bunch, A.J., 2010, Colorado River fish monitoring in Grand Canyon, Arizona —-2000 to 2009 summary: U.S. Geological Survey Open-File Report 2010-1246, 26 p., accessed on November 5, 2010, at http://pubs.usgs.gov/of/2010/1246/. Melis, T.S., Topping, D.J., Grams, P.E., Rubin, D.M., Wright, S.A., Draut, A.E., Hazel, J.E., Jr., Ralston, B.E., Kennedy, T.A., Rosi-Marshall, E., Korman, J., Hilwig, K.D., and Schmit, L.M., 2010, 2008 High-flow experiment at Glen Canyon Dam benefits Colorado River resources in Grand Canyon National Park: U.S. Geological Survey Fact Sheet 2010-3009, 4 p., accessed on July 27, 2010, at http://pubs.usgs.gov/fs/2010/3009/.

Rosi-Marshall, E.J., Kennedy, T.A., Kincaid, D.W., Cross, W.F., Kelly, H.A.W., Behn, K.A., White, T., Hall, R.O., Jr., and Baxter, C.V., 2010, Short-term effects of the 2008 highflow experiment on macroinvertebrates in the Colorado River below Glen Canyon Dam, Arizona: U.S. Geological Survey Open-File Report 2010-1031, 28 p., accessed on August 10, 2010, at http://pubs.usgs.gov/ of $/ 2010 / 1031 /$.

Yard, M.D., Coggins, L.G., Baxter, C.V., Bennett, G.E., and Korman, J., in press, Trout piscivory in the Colorado River, Grand Canyon - effects of turbidity, temperature, and fish prey availability: Transactions of the American Fisheries Society.

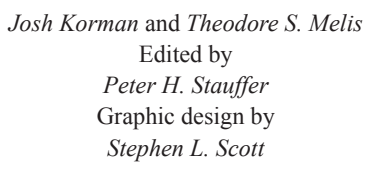

This Fact Sheet and any updates to it are available online at: http://pubs.usgs.gov/fs/2011/3002 